\title{
UPAYA PENINGKATAN PEMAHAMAN GURU BAHASA INGGRIS SMA MENGENAI MODEL PEMBELAJARAN SASTRA BERBAHASA INGGRIS
}

\author{
Delvi Wahyuni ${ }^{*}$, Witri Oktavia ${ }^{2}$, Halma Zakiyah $^{2}$ dan Silva Afdian ${ }^{3}$ \\ ${ }^{1}$ Prodi Sastra Inggris, Universitas Negeri Padang \\ ${ }^{2}$ Program Studi Pendidikan Bahasa Inggris, Universitas Negeri Padang \\ ${ }^{3}$ Program Studi Pendidikan Bahasa Inggris, Universitas Negeri Padang \\ ${ }^{4}$ Prodi Pendidikan Bahasa Inggris, Universitas Negeri Padang \\ Jl. Prof. Dr. Hamka Kampus UNP Air Tawar, Padang \\ E-mail: Delvi_wahyuni@fbs.unp.ac.id
}

\begin{abstract}
ABSTRAK. Tujuan dari kegiatan ini adalah menyelesaikan permasalahan yang dihadapi oleh guru bahasa Inggris SMA dalam mengajarkan teks sastra berbahasa Inggris. Solusi yang ditawarkan oleh Tim Pelaksana adalah pelatihan mengenai model pembelajaran sastra terintegrasi (Integrated Approaches to Teaching Literature). Metode yang digunakan adalah metode workshop yang berlangsung selama kurun waktu empat bulan (Agustus-November, 2019) di SMAN 1 IV Angkek. Peserta dari kegiatan ini adalah empat orang guru bahasa Inggris yang mengajar di SMAN 1 IV Angkek dan SMAN 1 Canduang, Kabupaten Agam, Sumatera Barat. Selain itu terdapat sepuluh orang siswa yang dilibatkan dalam kegiatan ini untuk keperluan demonstrasi materi yang diberikan dalam pelatihan ini. Berdasarkan hasil evaluasi, kegiatan ini terlaksana dengan baik. Kemudian, peserta juga memetik manfaat dari kegiatan ini dalam hal membantu mereka memahami materi sastra berbahasa Inggris serta pembelajarannya. Peserta juga menyukai materi yang diberikan. Dalam hal ini, peserta guru paling menyukai materi tentang puisi berbahasa Inggris. Sementara itu, peserta siswa paling menyukai materi lagu berbahasa Inggris. Kemudian, capaian yang dapat dilaporkan adalah peserta sudah memiliki pemahaman yang baik mengenai sastra berbahasa Inggris dan pembelajarannya.
\end{abstract}

Kata kunci: Sastra dalam bahasa Inggris; Pendekatan Terpadu untuk Pengajaran Sastra; Guru Bahasa Inggris

ABSTRACT. The objective of this program is to help English teachers working with senior high school students to teach literature in English. A specially designed workshop on integrated approaches to teaching literature was held from August to November 2019. The participants were four English teachers from SMAN 1 IV Angkek and SMAN 1 Canduang, Agam Regency, West Sumatera. Ten students also took part in this program. The presence of these students was necessary for the demonstration of classroom practices for integrated approaches to teaching literature. An after-program survey was conducted as a means to evaluate the program. Results show that it was well delivered proven by high satisfaction rate from the participants. They claimed to benefit from this program because the topics covered in the workshop relevant with their needs. The participant also reported improved knowledge about literature in English and approaches to teaching it.

\section{Keywords: Literature in English; Integrated Approaches to Teaching Literature; English Teachers}

\section{PENDAHULUAN}

Pembelajaran sastra Inggris di tingkat SMA sederajat merupakan amanat dari Kurikulum 2013 (Kurtilas) yang tertuang dalam Peraturan Menteri Pendidikan dan Kebudayaan Republik Indonesia No. 81a Tahun 2013. Dalam hal ini teks yang wajib diajarkan kepada siswa adalah cerita pendek (short story), puisi (poem/poetry), peribahasa (proverb) dan lagu (song). Bagi guru bahasa Inggris (selanjutnya disebut Mitra) di SMAN 1 Ampek Angkek dan SMAN 1 Canduang, Kabupaten Agam, Sumatera Barat, kebijakan baru ini menimbulkan permasalahan. Dalam hal ini, Mitra tidak mempunyai pengetahuan dan keterampilan yang cukup dalam mengajarkan teks sastra berbahasa Inggris. Menurut Mitra, permasalahan ini timbul karena beberapa hal. Pertama, sebelum Kurtilas berlaku, kurikulum yang dianut di Indonesia adalah KTSP dimana teks sastra berbahasa Inggris tidak diajarkan (Rahmi, 2014). Kedua, Mitra tidak mempunyai latar belakang pendidikan yang cukup di bidang sastra berbahasa Inggris dan pembelajarannya di tingkat SMA. Ketiga, minimnya pelatihan yang diberikan oleh sekolah maupun institusi pemerintah terkait mengenai pembelajaran sastra berbahasa Inggris di SMA. Menurut Ortells (2013), hal ini adalah salah satu penyebab keengganan guru dalam mengajarkan sastra berbahasa Inggris kepada siswa. Jika dibawa ke konteks yang lebih besar, kajian yang dilakukan oleh Rahmi (2014) menunjukkan bahwa sekolah dan guru tidak siap untuk materi baru ini. Keempat, masih sedikitnya kepustakaan mengenai hal ini sehingga Mitra kesulitan dalam mencari rujukan tentang bagaimana mengajarkan sastra berbahasa Inggris di SMA. Akibatnya, tuntutan Kurtilas sering tidak diimplementasikan dengan baik di sekolah Mitra. Oleh karena itu, untuk memperbaiki situasi, Mitra merasa membutuhkan pelatihan mengenai model pembelajaran sastra berbahasa Inggris yang sesuai dengan tingkat SMA di konteks Indonesia.

Untuk Mitra yang bertugas di SMAN 1 IV Angkek Canduang, mereka pernah mendapatkan pelatihan mengenai cara mengajarkan puisi berbahasa 
Inggris di tahun 2018. Meskipun demikian, Mitra merasa bahwa pelatihan mengenai cara mengajarkan teks sastra berbahasa Inggris masih sangat diperlukan (Triya Nofa, wawancara, Januari 20, 2019), (Delvi Wahyuni dan Witri Oktavia, 2018). Menurut Mitra, mereka masih kesulitan dalam mengajarkan peribahasa berbahasa Inggris dan lagu berbahasa Inggris. Oleh sebab itu, pelatihan mengenai model pembelajaran untuk teks tersebut diatas adalah sangat urgen. Sementara itu bagi Mitra yang bertugas di SMAN 1 Canduang, pelatihan seperti ini belum pernah mereka dapatkan sebelumnya. Namun, kedua Mitra setuju bahwa pelatihan yang sama untuk teks cerita pendek berbahasa Inggris tidak terlalu mendesak karena mereka sudah terbiasa dalam mengajarkan teks tersebut. Oleh karena itu, kegiatan yang berlangsung dari bulan Agustus sampai dengan November 2019 ini difokuskan kepada pelatihan model pembelajaran yang bisa diimplementasikan oleh Mitra untuk mengajarkan teks puisi, peribahasa dan lagu berbahasa Inggris.

Setelah permasalahan prioritas ditentukan, maka tujuan dari program ini menjadi jelas. Dengan ini, tujuan dari kegiatan ini adalah melatih Mitra dalam hal model pembelajaran yang bisa mereka gunakan dalam mengajarkan teks sastra berbahasa Inggris kepada siswa SMA. Untuk tujuan itu, Tim Pelaksana menawarkan solusi yang berbentuk sebuah pelatihan mengenai model pembelajaran terintegrasi untuk teks sastra berbahasa Inggris (Integrated Approaches to Teaching Literature). Model yang dilatihkan ini diprakarsai oleh ahli pembelajaran bahasa dan sastra seperti Duff \& Maley (1990), Savvidou (2004), dan Healy (2010). Beberapa kajian juga menunjukkan kemangkusan dari pendekatan ini (Divsar \& Tahriri, 2009; Aziz \& Nasharudin, 2010; Yimwilai, 2015).

Menurut Yimwilai (2015) sebuah pendekatan pembelajaran dikatakan terintegrasi ketika sebuah konsep diajarkan dengan menggunakan berbagai pendekatan dan disiplin ilmu. Menurut Carter \& Long (1991), pendekatan dalam pembelajaran sastra adalah (a) pendekatan bahasa (language model), (b) pendekatan budaya (cultural model), dan (c) pendekatan pengembangan diri (personal growth model). Lebih lanjut, Carter \& Long (1991) menjelaskan bahwa mereka yang menerapkan pendekatan bahasa dalam mengajarkan bahasa percaya bahwa sastra sangat bermanfaat dalam proses pembelajaran sebuah bahasa. Kemudian, menurut Carter \& Long (1991), mereka yang mengajarkan sastra dengan pendekatan budaya beranggapan bahwa sastra merupakan media untuk mempelajari nilai sosial dan kebudayaan yang terkandung dalam sebuah karya sastra. Sementara itu, menurut Carter \& Long (1991) tujuan utama dari pendekatan pengembangan diri adalah membuat siswa mempunyai kecintaan terhadap karya sastra bahkan setelah mereka selesai mempelajari teks tersebut. Masih menurut Carter \& Long (1991), tujuan ini dapat dicapai ketika teks yang dipelajari relevan dengan konteks siswa sehingga mereka bisa mengaitkan pengalaman mereka dengan apa yang diceritakan dalam sebuah karya sastra.

Meskipun ketiga model pembelajaran sastra yang dikemukakan oleh Carter \& Long (1991) ini mempunyai fokus masing-masing, tapi penerapan satu model saja untuk mengajarkan sastra untuk siswa SMA di konteks Indonesia dirasa tidak cukup untuk mencapai tujuan pembelajaran sastra itu sendiri. Dalam pendekatan berbasis bahasa, karya sastra menjadi sebuah media untuk mengajarkan komponen dan keahlian bahasa (Carter \& Long, 1991; Lazar, 1993; Hall, 2005; Rashid, Vethamani, \& Rahman, 2010; Mustakim, Mustapha, \& Lebar, 2014; Dhillon \& Mogan, 2014; Silva Afdian \& Delvi Wahyuni, 2020). Namun, pendekatan ini dapat menjadikan pelajaran sastra menjadi monoton, sehingga siswa tidak merasakan kegembiraan atau hiburan yang semestinya mereka dapatkan dari karya tersebut (Carter \& Long, 1991; Al Sabiri \& Kaymakamoğlu, 2019). Pada pendekatan budaya, siswa diperkenalkan kepada nilai-nilai universal melalui karya sastra (Carter \& Long, 1991; Savvidou, 2004; Hall, 2005; Hwang \& Embi, 2007; Healy, 2010; Rashid, Vethamani, \& Rahman, 2010). Meskipun demikian, pendekatan ini membuat suasana pembelajaran terpusat pada guru dan tidak ada manfaat berarti bagi penguasaan bahasa (Savvidou, 2004; Dong, 2005). Pada pendekatan pengembangan diri, karya sastra berfungsi sebagai wadah perangsang untuk mengembangkan diri sendiri (Carter \& Long, 1991; Lazar, 1993; Savvidou, 2004; Hwang \& Embi, 2007; Rashid, Vethamani, \& Rahman, 2010; Mustakim, Mustapha, \& Lebar, 2014; Iskhak, 2015). Tapi, pada situasi pembelajaran bahasa asing, pendekatan ini akan sulit diterapkan bila siswa tidak bisa memahami teks bahasa asing yang sedang mereka pelajari karena faktor kesulitan bahasa (Trisnawati, 2009; Iskhak, 2015).

Terkait dengan konteks Mitra yang mengajar di situasi dimana bahasa Inggris bukanlah bahasa sehari-hari, maka pendekatan dalam mengajarkan sastra berbahasa Inggris harus mempertimbangkan berbagai faktor agar tujuan pembelajaran dapat dicapai. Menurut Duff dan Maley (dalam Savvidou, 2004) ada tiga alasan kenapa pembelajaran sastra berbahasa asing di sekolah harus menerapkan pendekatan terintergrasi, yaitu:

a. Alasan linguistik. Teks sastra merupakan sebuah teks otentik sehingga teks tersebut bisa mengenalkan siswa terhadap berbagai tipe penggunaan dan struktur bahasa yang sedang dipelajari. 
b. Alasan metodologis. Dengan membaca karya sastra, siswa bisa diperkenalkan kepada keahlian lain terkait dengan penguasaan bahasa asing. Salah satu keahlian yang dimaksud adalah keahlian dalam penggunaan strategi membaca atau skema membaca.

c. Alasan motivasi. Membaca karya sastra punya tujuan ganda. Selain untuk dinikmati sebagai hiburan, karya sastra juga bisa menjadi sumber motivasi bagi siswa untuk mengemukakan pendapat mereka terkait dengan apa yang sedang mereka baca.

Berdasarkan ulasan diatas dapat disimpulkan bahwa tujuan penggunaan berbagai jenis pendekatan dalam mengajarkan sastra berbahasa asing adalah untuk memaksimalkan manfaat yang bisa didapatkan oleh siswa dari teks sastra tersebut. Dalam hal ini, mereka memperoleh penguasaan bahasa; wawasan budaya; pengembangan diri dan juga hiburan.

\section{METODE}

Metode yang dipilih untuk menyelesaikan permasalahan mitra adalah metode pelatihan dimana Tim Pelaksana melakukan penyuluhan mengenai model pembelajaran sastra dan memperagakan bagaimana implementasi model tersebut. Peserta pelatihan ini terdiri dari tiga orang guru bahasa Inggris di SMAN 1 IV Angkek dan 1 orang guru bahasa Inggris di SMAN 1 Canduang. Selain melibatkan guru, pelatihan ini juga mengikutsertakan sepuluh orang siswa dari kedua SMA Mitra. Peran dari sepuluh siswa ini sangat penting dalam pemeragaan bagaimana mengajarkan teks sastra berbahasa Inggris dengan model terintegrasi kepada guru. Sementara itu, narasumber untuk pelatihan ini terdiri dari Tim Pelaksana dan satu orang narasumber undangan. Narasumber undangan ini diminta untuk memberikan materi terkait dengan strategi mengajarkan lagu berbahasa Inggris kepada siswa. Meskipun Tim Pelaksana memiliki keahlian dibidang pembelajaran sastra berbahasa Inggris, Tim Pelaksana masih membutuhkan bantuan narasumber yang lain dibidang lagu, unsur sebuah lagu, teknik menyanyi, dan pembentukan paduan suara. Dalam hal ini, paduan suara adalah salah satu strategi pembelajaran lagu berbahasa Inggris yang menjadi salah satu materi dari pelatihan ini.

Sebagaimana selayaknya sebuah program pelatihan, dalam kegiatan ini juga dilaksanakan semacam asesmen dan evaluasi. Untuk tujuan itu, pada akhir pelaksanaan kegiatan, Tim Pelaksana membagikan angket kepada semua peserta kegiatan. Angket tersebut terdiri dari pertanyaan-pertanyaan mengenai (a) manfaat kegiatan bagi pemahaman peserta terhadap teks sastra berbahasa Inggris, (b) pelaksanaan kegiatan, (c) materi yang paling disukai selama pelatihan, dan (d) capaian pelaksanaan kegiatan. Adapun pengumpulan data untuk tujuan evaluasi ini dilakukan dengan bantuan google form. Data kemudian diolah dengan menggunakan komputasi yang terdapat di perangkat lunak Microsoft Excel.

Pelaksanaan kegiatan yang mengambil lokasi di SMAN I Ampek Angkek ini melalui beberapa tahapan. Tahapan pertama adalah tahapan analisa situasi, dimana Mitra dan Tim Pelaksana mendiskusikan permasalahan yang dihadapi Mitra terkait dengan pembelajaran bahasa Inggris di tingkat SMA. Kemudian, masalah prioritas diidentifikasi. Dalam hal ini, masalah yang ingin diselesaikan adalah peningkatan pengetahuan dan keterampilan Mitra mengenai pembelajaran puisi, peribahasa dan lagu berbahasa Inggris. Selanjutnya pelaksanaan kegiatan dalam bentuk sebuah pelatihan dan workshop dengan urutan materi (1) puisi berbahasa Inggris, (2) peribahasa berbahasa Inggris, (3) lagu berbahasa Inggris. Tahapan berikutnya adalah tahapan evaluasi. Selanjutnya, Tim Pelaksana membuat produk pelatihan berupa sertifikat untuk peserta dan penulisan luaran kegiatan berupa sebuah artikel ilmiah mengenai kegiatan yang telah dilaksanakan. Alur dari pelaksanaan kegiatan dapat dilihat pada diagram berikut:

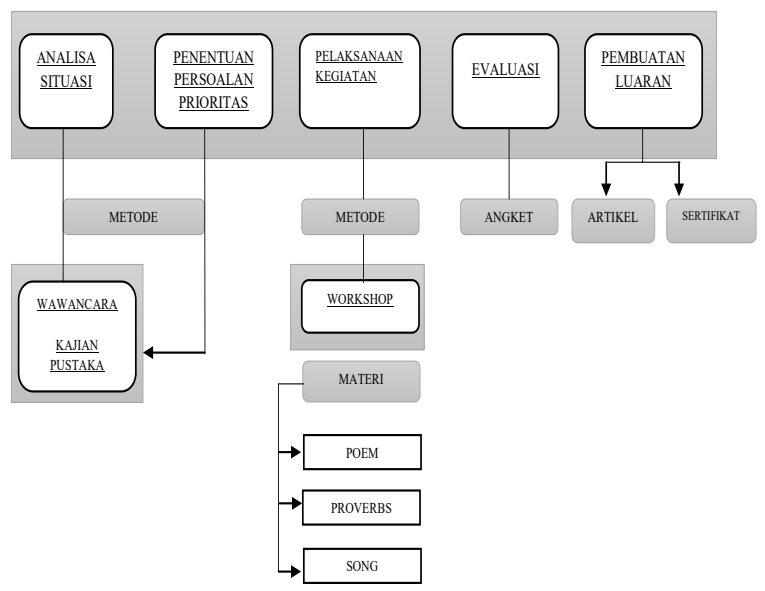

Gambar 1. Alur Kegiatan Pelaksanaan

\section{HASIL DAN PEMBAHASAN}

Pada bagian ini dibahas mengenai hasil kegiatan pelatihan mengenai model pembelajaran sastra berbahasa Inggris untuk guru di dua SMAN di Kabupaten Agam, Sumatera Barat. Bagian ini terdiri dari pembahasan mengenai (1) pelaksanaan kegiatan, (2) manfaat kegiatan bagi peserta, (3) materi yang diberikan selama pelatihan, dan (4) Capaian kegiatan dari perspektif peserta.

Hasil mengenai pelaksanaan kegiatan dapat dilihat pada tabel berikut. 
Tabel 1. Evaluasi Pelaksanaan Kegiatan

\begin{tabular}{|c|c|c|c|c|}
\hline No & Pernyataan & $\begin{array}{c}\text { Guru } \\
(\%)\end{array}$ & $\begin{array}{c}\text { Siswa } \\
(\%)\end{array}$ & $\begin{array}{c}\text { Rata- } \\
\text { rata }(\%)\end{array}$ \\
\hline 1 & $\begin{array}{l}\text { Kegiatan ini terlaksana } \\
\text { dengan baik }\end{array}$ & 81 & 93 & 87 \\
\hline 2 & $\begin{array}{l}\text { Tim Pelaksana menyediakan } \\
\text { kelengkapan peralatan penun- } \\
\text { jang, alat tulis dan konsumsi } \\
\text { untuk kegiatan dengan baik }\end{array}$ & 94 & 95 & 95 \\
\hline 3 & $\begin{array}{l}\text { Tim Pelaksana mendokumen- } \\
\text { tasikan kegiatan dengan baik }\end{array}$ & 88 & 85 & 87 \\
\hline 4 & $\begin{array}{l}\text { Narasumber menguasai } \\
\text { materi dengan baik }\end{array}$ & 100 & 93 & 97 \\
\hline 5 & $\begin{array}{l}\text { Narasumber menyampaikan } \\
\text { materi dengan baik }\end{array}$ & 94 & 93 & 94 \\
\hline 6 & $\begin{array}{l}\text { Narasumber berperilaku baik } \\
\text { selama pelaksanaan kegiatan }\end{array}$ & 94 & 100 & 97 \\
\hline 7 & $\begin{array}{l}\text { Narasumber menyiapkan media } \\
\text { ajar pelatihan dengan baik }\end{array}$ & 100 & 98 & 99 \\
\hline 8 & $\begin{array}{l}\text { Bahan ajar pelatihan } \\
\text { dirancang dengan baik }\end{array}$ & 94 & 90 & 92 \\
\hline 9 & $\begin{array}{l}\text { Saya ingin adanya kegiatan } \\
\text { serupa di masa depan untuk } \\
\text { materi lain }\end{array}$ & 94 & 98 & 96 \\
\hline
\end{tabular}

Sumber: Data Angket yang disebar pada saat pelaksanaan kegiatan

Secara rata-rata, item pertanyaan yang mendapatkan skorpaling tinggi adalah itemmengenai media ajar. Sementara itu item pertanyaan yang mendapatkan skor paling rendah adalah pelaksanaan kegiatan. Meskipun demikian, pada umumnya pelaksanaan kegiatan ini berlangsung dengan baik. Baik guru atau siswa yang menjadi peserta kegiatan ini memberikan skor yang tinggi terhadap item-item pertanyaan pada angket ini.

Secara kumulatif, bagian terbaik dari pelaksanaan ini adalah media ajar yang disiapkan oleh Tim Pelaksana. Item ini mendapatkan skor $99 \%$. Terkait dengan pelaksanaan kegiatan, $87 \%$ responden menyatakan bahwa kegiatan ini terlaksana dengan baik. Dalam hal ini, peserta siswa mempunyai persepsi yang lebih baik dari peserta guru seperti tercermin dari persentase berikut (93\% dibanding dengan $81 \%$ ). Selanjutnya, $96 \%$ responden menyatakan bahwa mereka ingin ada kegiatan serupa di masa yang akan datang. Hal ini menandakan kalau kegiatan memang berlangsung dengan baik sehingga menimbulkan kesan yang bagus bagi peserta. Hal lain yang patut dilaporkan adalah semua responden dari kalangan guru setuju kalau narasumber menguasai materi dengan baik serta menyiapkan media ajar pelatihan dengan baik. Untuk item pertanyaan tersebut persentase dari responden siswa juga tergolong tinggi (93\% dan 98\%). Sementara itu, semua responden dari kalangan siswa menganggap bahwa narasumber berperilaku baik selama pelaksanaan kegiatan. Sedangkan persentase item pertanyaan tersebut dari kalangan guru adalah $94 \%$. Untuk item-item pertanyaan lainnya, persentase penilaian peserta siswa dan peserta guru terhadap pelaksanaan kegiatan nyaris sama.

Hasil mengenai manfaat kegiatan bagi peserta terlihat pada tabel berikut:

\section{Tabel 2. Manfaat kegiatan bagi Pemahaman Guru terhadap Teks Sastra berbahasa Inggris}

\begin{tabular}{clc}
\hline No & \multicolumn{1}{c}{ Pertanyaan } & \% \\
\hline 1 & $\begin{array}{l}\text { Kegiatan ini bermanfaat dalam membantu saya } \\
\text { memahami puisi berbahasa Inggris dengan baik }\end{array}$ & 94 \\
2 & $\begin{array}{l}\text { Kegiatan ini bermanfaat dalam membantu saya } \\
\text { memahami peribahasa berbahasa Inggris dengan } \\
\text { baik }\end{array}$ & 81 \\
3 & $\begin{array}{l}\text { Kegiatan ini bermanfaat dalam membantu saya } \\
\text { memahami lagu berbahasa Inggris dengan baik }\end{array}$ & 94 \\
4 & $\begin{array}{l}\text { Saya menyukai materi yang diberikan dalam } \\
\text { pelatihan ini }\end{array}$ & 94 \\
5 & $\begin{array}{l}\text { Saya suka mempelajari teks sastra berbahasa } \\
\text { Inggris }\end{array}$ & Saya suka mengajarkan teks sastra berbahasa \\
6 & $\begin{array}{l}\text { Inggris } \\
\text { Kegiatan ini relevan dengan kebutuhan saya terkait } \\
\text { dengan model pembelajaran sastra berbahasa }\end{array}$ & 75 \\
\hline
\end{tabular}

Sumber: Data angket yang disebar pada saat pelaksanaan kegiatan

Secara garis besar, hasil yang terlihat di Tabel 2 menunjukkan bahwa peserta guru menganggap kegiatan bermanfaat. Sebanyak $94 \%$ peserta guru menyatakan bahwa kegiatan ini relevan dengan kebutuhan terhadap pelatihan mengenai model pembelajaran sastra berbahasa Inggris untuk siswa SMA. Kemudian, 94\% peserta guru menyatakan kalau mereka menyukai materi yang diberikan dalam kegiatan kali ini. Berdasarkan jenis teks sastra yang diberi, $94 \%$ guru menyatakan kalau kegiatan ini bermanfaat dalam membantu mereka memahami puisi berbahasa Inggris dan lagu berbahasa Inggris. Kemudian, sebanyak 81 \% guru menyatakan kegiatan ini membantu mereka memahami peribahasa dalam bahasa Inggris. Terkait dengan minat guru untuk mempelajari sastra berbahasa Inggris, $81 \%$ menyatakan demikian. Sementara itu hanya tiga perempat dari peserta guru yang menyatakan bahwa mereka suka mengajarkan sastra berbahasa Inggris.

Bahwa rendahnya persentase item mengenai kesukaan guru dalam mengajarkan teks sastra berbahasa Inggris sudah diprediksi oleh Tim Pelaksana sebelumnya. Persentase yang didapat pada hasil ini mungkin jauh lebih baik dibanding dengan jika angket disebar sebelum kegiatan pelatihan dilakukan. Jika ditilik dari rujukan yang ada, rendahnya minat guru dalam mengajarkan teks sastra karena (1) guru mengalami kesulitan memahami teks sastra karena faktor bahasa dan budaya (Rashid, Vethamani, \& Rahman, 2010; Padurean, 2015; Tevdovska, 2016; Hassan, 2018), (2) guru merasa tidak percaya diri (Musthafa, 2015; Muthusamy, 
Salleh, Michael, Arumugam \& Thayalan, 2017), (3) kurangnya pendidikan atau pelatihan mengenai pembelajaran sastrabagiguru(Omar,2017; Musthafa, 2015; Delvi Wahyuni dan Witri Oktavia, 2018), (4) rendahnya kemampuan siswa dalam memahami teks sastra (Hwang \& Embi, 2007; Rashid, Vethamani, \& Rahman, 2010; Hassan, 2018), (5) guru kesulitan dalam mencari sumber rujukan untuk topik sastra berbahasa Inggris (Hwang \& Embi, 2007; Rahmi, 2014; Muthusamy, Salleh, Michael, Arumugam \& Thayalan, 2017; Delvi Wahyuni dan Witri Oktavia, 2018), dan (6) rendahnya minat siswa untuk mempelajari teks sastra berbahasa Inggris (Padurean, 2015; Alfauzan \& Hussain, 2017). Dalam kaitannya dengan kegiatan yang sudah dilaksanakan, sebagian besar faktor-faktor ini disebut oleh Mitra sebagai alasan mengapa mereka memerlukan pelatihan mengenai model pembelajaran sastra berbahasa Inggris. Kesimpulannya, hasil ini menunjukkan bahwa kegiatan yang dilakukan adalah bermanfaat dan bersifat urgen.

Pada tahapan evaluasi, peserta siswa juga ditanya mengenai pendapat mereka tentang manfaat kegiatan ini. Hasil dari angket tersebut dapat dilihat di Tabel 3.

Tabel 3. Manfaat kegiatan bagi Pemahaman Siswa terhadap Teks Sastra berbahasa Inggris

\begin{tabular}{clc}
\hline No & \multicolumn{1}{c}{ Pernyataan } & \% \\
\hline 1 & $\begin{array}{l}\text { Kegiatan ini bermanfaat dalam membantu saya } \\
\text { memahami puisi berbahasa Inggris dengan baik }\end{array}$ & 83 \\
2 & $\begin{array}{l}\text { Kegiatan ini bermanfaat dalam membantu saya } \\
\text { memahami peribahasa berbahasa Inggris dengan } \\
\text { baik }\end{array}$ & 88 \\
3 & $\begin{array}{l}\text { Kegiatan ini bermanfaat dalam membantu saya } \\
\text { memahami lagu berbahasa Inggris dengan baik }\end{array}$ & 95 \\
4 & $\begin{array}{l}\text { Saya menyukai materi yang diberikan dalam } \\
\text { pelatihan ini }\end{array}$ & 90 \\
5 & $\begin{array}{l}\text { Saya suka mempelajari teks sastra berbahasa } \\
\text { Inggris }\end{array}$ & 93 \\
\hline
\end{tabular}

Sumber: Data angket yang disebar pada saat pelaksanaan kegiatan

Secara umum dapat dinyatakan bahwa siswa menganggap kegiatan ini bermanfaat. Dalam hal ini, sebanyak $90 \%$ siswa menyatakan bahwa mereka menyukai materi yang diberikan dalam kegiatan ini. Terkait dengan kesukaan mereka terhadap sastra berbahasa Inggris, 93\% menyatakan kalau mereka suka mempelajari teks sastra berbahasa Inggris. Jika dibahas berdasarkan jenis teks sastra yang diajarkan, lagu berbahasa Inggris mendapat persentase tertinggi (95\%), disusul oleh peribahasa dan puisi berbahasa Inggris ( $88 \%$ dan $83 \%$, secara berurutan).

Lebih rendahnya persentase untuk teks puisi berbahasa Inggris dibandingkan dengan teks lain bukanlah hal yang hanya berlaku di konteks Indonesia saja. Dalam hal ini, dibanding dengan teks sastra lain, mempelajari puisi berbahasa asing memang tidak terlalu disukai oleh siswa (Khatib, 2011; Tevdovska, 2016; Nobles \& Azano, 2016). Berdasarkan rujukan yang ada, teks puisi cenderung dianggap rumit sehingga susah untuk dipahami (Kim, 2004; Khatib, 2011;Utami, 2012; Halma Zakiyah dan Delvi Wahyuni, 2020). Menurut Kirszner dan Mandell (2000), berbeda dengan prosa, kata bantu dan keterangan panjang tidak ada dalam puisi karena pada hakikatnya puisi itu adalah karya sastra yang bertujuan untuk menyampaikan sebuah pengalaman dengan bahasa yang sangat padat. Oleh karena itu, untuk memahami sebuah teks puisi maka pembaca harus bekerja keras untuk menguraikan teks sehingga pemahaman dan pemaknaan bisa didapatkan. Tentu saja, tantangan pemahaman puisi akan bertambah jika puisi tersebut ditulis dalam bahasa asing.

Pada tahapan evaluasi, Tim Pengabdi juga menganggap penting untuk melihat materi mana yang paling disenangi oleh peserta. Hasil angket ini dapat dilihat pada tabel berikut:

\section{Tabel 4. Materi yang disukai Peserta}

\begin{tabular}{llccc}
\hline No & \multicolumn{1}{c}{ Pernyataan } & $\begin{array}{c}\text { Guru } \\
(\mathbf{\%})\end{array}$ & $\begin{array}{c}\text { Siswa } \\
(\mathbf{\%})\end{array}$ & $\begin{array}{c}\text { Rata- } \\
\text { rata (\%) }\end{array}$ \\
\hline 1 & $\begin{array}{l}\text { Saya sangat menyukai } \\
\text { materi mengenai puisi } \\
\text { berbahasa Inggris }\end{array}$ & 94 & 90 & 92 \\
2 & $\begin{array}{l}\text { Saya sangat menyukai } \\
\text { materi mengenai peribahasa } \\
\text { Inggris }\end{array}$ & 81 & 88 & 85 \\
3 & $\begin{array}{l}\text { Saya sangat menyukai } \\
\text { materi mengenai lagu } \\
\text { berbahasa Inggris }\end{array}$ & 98 & 93 \\
\hline & $\quad$ Sumber: Data angket yang disebar pada saat pelaksanaan kegiatan
\end{tabular}

Tabel 4 menunjukkan bahwa materi yang paling disukai oleh peserta adalah lagu berbahasa Inggris; sementara itu, materi yang paling tidak disukai adalah peribahasa berbahasa Inggris. Dalam hal ini, 93\% peserta menyatakan bahwa mereka sangat menyukai materi mengenai lagu berbahasa Inggris. Untuk materi puisi berbahasa Inggris, persentasenya adalah $92 \%$. Sedangkan untuk materi peribahasa berbahasa Inggris, hanya $85 \%$ peserta yang menyatakan menyukainya.

Ada dua hal yang dapat menjelaskan kenapa materi peribahasa berbahasa Inggris mendapatkan persentase yang lebih dari rendah teks sastra yang lain. Faktor yang pertama adalah faktor bahasa dan budaya. Pada saat penyajian materi ini, narasumber menyandingkan peribahasa berbahasa Inggris dan padanannya dalam bahasa Indonesia. Walaupun peserta akhirnya mengetahui padanan sebuah peribahasa bahasa Inggris dalam bahasa Indonesia tapi untuk memahami peribahasa berbahasa Inggris 
itu sendiri masih menjadi masalah. Menurut Mitra, mereka tidak bisa memahami mengapa ekspresi yang ada dalam sebuah peribahasa berbahasa Inggris itu bisa bermakna seperti yang dimaksudkan. Rujukan yang ada juga mengatakan bahwa mempelajari peribahasa dalam bahasa asing tidaklah mudah tanpa pengetahuan yang cukup terkait latar budaya sebuah peribahasa (Naznean, 2015; Daşkına \& Hatipoğlu, 2019). Selain itu, materi peribahasa juga merupakan materi yang paling tidak mendapat perhatian dalam pembelajaran bahasa Inggris terutama pada kelas pembelajaran bahasa Inggris yang menggunakan pendekatan grammar dan hanya diajarkan untuk mengisi waktu luang. (Akbarian, 2010; Gözpinar, 2014; Indrawati, 2019). Dalam hal ini, Mitra juga menyatakan bahwa jika tidak diwajibkan oleh kurikulum, mereka mungkin tidak akan mengajarkan materi ini kepada siswa. Kedua, materi peribahasa berbahasa Inggris tidak diikuti dengan kegiatan kelas yang bersifat pemeragaan. Pada materi puisi berbahasa Inggris, peserta bisa mendengarkan cara mendeklamasikan puisi berbahasa Inggris dan kemudian bisa mempraktekkannya di hadapan peserta lain. Sementara itu, untuk materi lagu berbahasa Inggris terdapat penampilan paduan suara (choir). Menurut peserta mereka sangat terkesan dengan materi ini. Peserta guru tidak pernah menyangka bahwa materi lagu berbahasa Inggris bisa disajikan dengan cara ini. Sementara itu, siswa menyatakan bahwa mereka baru menyadari kalau mereka punya potensi dalam hal seni tarik suara. Dalam hal ini, Tim pelaksana tidak membeda-bedakan siswa berdasarkan suara mereka sehingga semuanya menjadi anggota paduan suara.

Sebelumnya telah dibahas bahwa adalah sebuah tantangan yang berat untuk memahami teks puisi dalam bahasa Inggris. Sehingga untuk peserta siswa, hanya sekitar $83 \%$ siswa yang menyatakan bahwa pelatihan ini meningkatkan pemahaman mereka terhadap puisi berbahasa Inggris. Akan tetapi, ketika ditanya mengenai materi yang paling disukai, persentase untuk puisi berbahasa Inggris lebih tinggi dari persentase untuk teks lain. Perlu disebutkan dalam pembahasan ini bahwa siswa yang mengikuti kegiatan ini adalah anggota dari English Club masing-masing sekolah Mitra. Dengan kata lain, mereka adalah siswa yang mempunyai motivasi yang tinggi untuk belajar bahasa Inggris. Menurut informasi dari peserta guru, para siswa ini juga tergolong siswa yang mempunyai kemampuan bahasa Inggris yang cukup baik. Hal lain yang perlu dipertimbangkan adalah lokasi sekolah yang berada di daerah dimana akses dan infrastruktur tergolong baik. Hasil yang sama belum tentu didapatkan jika peserta yang terlibat berasal dari sekolah yang terletak di daerah terpelosok. Dalam hal ini, infrastruktur, sumber belajar dan penguasaan bahasa adalah diantara tantangan yang dihadapi oleh guru di daerah pelosok sehingga pembelajaran bahasa Inggris di daerah seperti ini lebih buruk dibanding dengan yang dialami oleh rekan-rekan mereka yang bersekolah di kota besar (Febriana, Nurkamto, Rochsantiningsih, \& Muhtia dalam Permata, N. \& Hadiani, 2019).

Berikutnya dijabarkan hasil tentang capaian pelaksanaan kegiatan pelatihan model pembelajaran sastra berbahasa Inggris kepada Mitra. Hasil ini dapat dilihat di tabel berikut:

Tabel 5. Capaian Pelaksanaan Kegiatan oleh Berdasarkan Persepsi Peserta Guru

\begin{tabular}{|c|c|c|}
\hline No & Pernyataan & $\%$ \\
\hline 1 & $\begin{array}{l}\text { Materi yang diberikan pada program ini } \\
\text { mampu memecahkan permasalahan saya dalam } \\
\text { mengajarkan sastra berbahasa Inggris di SMA }\end{array}$ & 94 \\
\hline 2 & $\begin{array}{l}\text { Setelah mengikuti program ini kemampuan saya dalam } \\
\text { memahami teks sastra berbahasa Inggris meningkat }\end{array}$ & 94 \\
\hline 3 & $\begin{array}{l}\text { Setelah mengikuti program ini pengetahuan dan } \\
\text { wawasan saya mengenai sastra berbahasa Inggris } \\
\text { bertambah }\end{array}$ & 88 \\
\hline 4 & $\begin{array}{l}\text { Setelah mengikuti program ini pengetahuan dan } \\
\text { wawasan saya mengenai cara mengajarkan sastra } \\
\text { berbahasa Inggris bertambah }\end{array}$ & 94 \\
\hline 5 & $\begin{array}{l}\text { Setelah mengikuti program ini saya mampu } \\
\text { merancang RPP untuk mengajar teks sastra } \\
\text { berbahasa Inggris dengan baik }\end{array}$ & 75 \\
\hline 6 & $\begin{array}{l}\text { Saya akan merujuk materi yang diberikan dalam } \\
\text { program ini untuk merancang pembelajaran sastra } \\
\text { berbahasa Inggris di masa yang akan datang }\end{array}$ & 75 \\
\hline
\end{tabular}

Sumber: Data angket yang disebar pada saat pelaksanaan kegiatan

Secara garis besar dapat dinyatakan bahwa kegiatan ini mendapatkan capaian pelaksanaan yang baik. Sebanyak 94\% responden menyatakan bahwa pelatihan ini mampu memecahkan permasalahan mereka dalam mengajarkan sastra berbahasa Inggris di SMA. Kemudian, sebanyak 94\% responden juga menyatakan bahwa kemampuan mereka dalam memahami teks sastra berbahasa Inggris dan cara mengajarkannya meningkat. Mereka yang menyatakan bahwa wawasan mereka mengenai sastra berbahasa Inggris meningkat setelah mengikuti program ini adalah $88 \%$. Sementara itu, tiga perempat dari peserta menyatakan bahwa setelah mengikuti kegiatan pelatihan ini mereka mampu merancang RPP untuk mengajar teks sastra berbahasa Inggris. Terkait dengan materi yang diberikan, sekitar 75\% dari peserta akan merujuk materi tersebut dalam merancang pembelajaran sastra berbahasa Inggris di masa yang akan datang.

Berdasarkan pelaksanaan di lapangan dan hasil evaluasi yang bisa disajikan secara kuantitatif, Tim Pelaksana bisa menyatakan bahwa kegiatan ini berlangsung dengan baik dan tujuan kegiatan sudah tercapai. Meskipun demikian ada beberapa 
catatan mengenai hal-hal patut diperbaiki pada kegiatan selanjutnya. Pertama, untuk mengukur apakah materi yang diberikan mampu meningkatkan pemahaman Mitra mengenai model pembelajaran sastra Inggris, maka diperlukan pengukuran persepsi Mitra mengenai hal tersebut baik di awal maupun di akhir kegiatan. Apa yang sudah dilakukan adalah evaluasi di akhir kegiatan saja. Kedua, Tim Pelaksana perlu melakukan asesmen formatif dan sumatif terhadap pemahaman Mitra mengenai materi yang sudah diberikan. Ketiga, Mitra perlu dilibatkan untuk mempublikasikan kegiatan ini baik di media massa atau sarana lain sehingga masyarakat mengetahui terlaksananya kegiatan ini. Bagaimana pun juga kegiatan ini bersifat kemitraan. Dalam hal ini Tim Pelaksana dibiayai oleh Universitas Negeri Padang sehingga pihak universitas harus mendapatkan kredit yang sepatutnya terkait dengan sumbangsih universitas dalam menyelesaikan permasalahan yang ada dalam masyarakat.

\section{SIMPULAN}

Berdasarkan hasil dan pembahasan dapat disimpulkan beberapa hal. Pertama kegiatan berlangsung dengan baik dan tujuan pelaksanaan kegiatan ini dapat dicapai. Salah satu penanda dari keberhasilan ini adalah tingginya persentase pernyataan mitra mengenai pelaksanaan kegiatan serupa di masa yang akan datang. Kedua, kegiatan ini bermanfaat bagi peserta dalam hal meningkatkan pemahaman mereka terhadap sastra berbahasa Inggris. Bagi peserta guru, kegiatan telah membantu memecahkan permasalahan mereka dalam hal cara mengajarkan sastra berbahasa Inggris. Ketiga, materi yang diberikan disukai oleh Mitra dan berkontribusi dalam mengatasi masalah kurangnya pengetahuan dalam pembelajaran sastra berbahasa Inggris. Keempat, walaupun secara umum capaian kegiatan ini adalah baik, hasil menunjukkan bahwa capaian baru sampai pada tataran teori. Sementara itu, untuk Mitra menerapkan materi yang diberi pada pelatihan dalam menyusun RPP untuk pelajaran sastra berbahasa Inggris masih belum maksimal. Meskipun demikian, hal ini membuka peluang baru untuk diadakannya kegiatan serupa dengan lebih memperhatikan masalah mitra dalam penyusunan RPP untuk topik sastra berbahasa Inggris. Hal lainnya, juga terbuka peluang bagi Tim Pelaksana untuk menyusun materi ajar untuk sastra berbahasa Inggris yang bisa digunakan oleh guru SMA.

\section{DAFTAR PUSTAKA}

Akbarian, I. (2010). A spice of classroom: Incorporating proverbial expressions in EFL classes. Journal of Asia TEFL, 7(1), 221-238.
Al Sabiri, A.R. \& Kaymakamoğlu, S. E. (2019). A Study on the Views of English Literature Teachers about How to Teach English Literature: Libyan Higher Education Context. This Article Is Developed from an MA Thesis Which Was Written by Almakki Rumadhan Al Sabiri under the Supervision of Assist. Prof. Dr. Sibel Ersel Kaymakamoğlu and Presented at ICOPFE 2018. https://doi.org/DOI: 10.22559/folklor.951.

Alfauzan, A. H., \& Hussain, A. G. (2017). Attitude towards and Perception of Literature in EFL Setting:ACase Study on QUMale Undergraduate Students. English Language Teaching, 10(1), 1-17. https://doi.org/10.5539/elt.v10n1p1

Aziz, M. A., \& Nasharudin, S. N. S. (2010). An Investigation on Approaches Used to Teach Literature in the ESLClassroom:ACase Study of Sekolah Menengah Kebangsaan Taman Desa Skudai, Johor Bahru. (Unpublished).

Carter, R \& Long, M. (1991). Teaching Literature. London: Longman.

Daşkına, N.C. \& Hatipoğlu, Ç. (2019). A proverb learned is a proverb earned: Proverb instruction in EFL classrooms. Eurasian Journal of Applied Linguistics, 5(1), 57-88. https://doi.org/10.32601/ejal.543781

Delvi Wahyuni dan Witri Oktavia. (2018). PKM Kelompok Guru Bahasa Inggris Yang Mengalami Kesulitan Dalam Mengajarkan Puisi dalam Bahasa Inggris di SMAN 1 Ampek Angkek dan SMAN 1 Banuhampu Kabupaten Agam. Jurnal Pengabdian Kepada Masyarakat, 2(3).

Dhillon, K.K. \& Mogan, S. (2014). Language-Based Approaches To Understanding Literature: a Creative Activity Module. The English Teacher, XLIII(2), 63-78.

Divsar, H., \& Tahriri, A. (2009). Investigating the Effectiveness of an Integrated Approach to Teaching Literature in an EFL Context. PanPacific Association of Applied Linguistics, 13(2), 105-116.

Dong, Y. R. (2005). Taking a Cultural-Response Approach to Teaching Multicultural Literature. English Journal, 94(3), 55. https:// doi.org/10.2307/30046420

Duff, A. \& Maley, A. (1990). (n.d.). Literature. Oxford: Oxford University Press.

Gözpinar, H. (2014). English Teachers' Interest in Proverbs in Language Teaching. The Journal of International Social Research, 7(31), 611-617. 
Hall, G. (2005). Literature and Language Teaching: A guide for Teachers and Trainers. United Kingdom: Palgrave MacMillan.

Halma Zakiyah dan Delvi Wahyuni. (2020). An Evaluation of Poems in English Taught to Indonesian Senior High School Students. Journal of English Language Teaching, 9(1), 252-258.

Hassan, K. M. (2018). Difficulties Facing English Teachers in Teaching Literary Texts at Higher Secondary Level in Bangladesh. English Language and Literature Studies, 8(3), 15 26. https://doi.org/10.5539/ells.v8n3p15

Healy,S.(2010).LiteratureintheEFLClassroomFrom theory to practice. Retrieved from https://ksu. repo.nii.ac.jp/dspace/bitstream/10965/347/1/ AHSUSK_HS_42_178.pdf.

Hwang, D., \& Embi, M. A. (2007). Approaches Employed By Secondary School Teachers To Teaching the Literature. Jurnal Pendidik Dan Pendidikan, Jil. 22, 1-23.

Indrawati, S. (2019). Students' Understanding on Proverb: A Study of Learning in School. Proceeding of The 28 International Conference on Literature: " Literature as A Source of Wisdom,”342-349.

Iskhak. (2015). The Application of Reader-response Theory in Enhancing Student Teachers' Affective and Linguistic Growth: AClassroom Action Research in EFL Teacher Education in Indonesia. The English Teacher, 44(2), 43-57. Retrieved from http://search.proquest.com. virtual.anu.edu.au/docview/1711389274/F/5 D05B29836A74980PQ/35? accountid $=8330$

Khatib, M. (2011). A New Approach to Teaching English Poetry to EFL Students. Journal of Language Teaching and Research, 2(1), 164 169. https://doi.org/10.4304/jitr.2.1.164-169

Kim, H. (2004). Integrating poetry and dialogue journal writing into EFL curricula. The Journal of Asia TEFL, 1(2), 83-108.

Kirszner, L.G. dan Mandell, S.R. (2000). Literature: Reading, Reacting, Writing. USA: Harcourt, Inc.

Lazar, G. (1993). Literature and Language Teaching: A Guide for Teachers and Trainers.

Mustakim, S.S., Mustapha, R., \& Lebar, O. (2014). Teacher's Approaches in Teaching Literature : Observations of ESL Classroom. Malaysian Online Journal of Educational Science, 2(4), 35-44.
Musthafa, B. (2015). Seven Issues And Dilemmas in Literature Teaching in EFL Context: Lessons from Indonesia. Indonesian Journal of Applied Linguistics, 4(2), 136-145. https:// doi.org/10.17509/ijal.v4i2.690

Muthusamy, C., Salleh, S.M., Michael, A.S., Arumugam, A. N. \& Thalayan, X. (2017). Methods Used in Teaching and Learning of Literature in the ESL Classroom and Adult Learners' Attitude. Journal of Applied Linguistics and Language Research, 4(2), 17-25.Naznean, A. (2015). Difficulties in Teaching Idioms and Proverbs. Language and Discourse, 653-659.

Nobles, S.L. \& Azano, A.P. (2016). Poetry Is Powerful: High School Students and Pre- Service Teachers Develop Literacy Relationships through Poetry. Teaching/ Writing: The Journal of Writing Teacher Education, 5(1), 126-138.

Omar, Y. (2017). The Inclusion of Literature Components in Malaysian English Papers: the Challenges and Pros in Teaching and Learning. Al-Ta Lim Journal, 24(3), 174-186. https://doi.org/10.15548/jt.v24i3.335

Ortells, E. (2013). Teaching English as a foreign language in Spanish secondary schools: The value of literature. English Teaching, 12(1), 91-100.

Padurean, A. N. (2015). Approaches to Teaching Literature in EFL Classroom. Journal Of Romanian Literary Studies, (6), 195-200. https://doi.org/10.1017/ CBO9781107415324.004

Peraturan Menteri Pendidikan dan Kebudayaan Republik Indonesia No 81a Tahun 2013. Implementasi Kurikulum.

Permata, N. \& Hadiani, D. (2019). Pelatihan Bahasa Inggris Dalam Upaya Peningkatan Kemampuan Mahasiswa Bidikmisi Polman Bandung. Masyarakat. Jurnal Pengabdian Kepada, 2(4).

Rahmi, M. (2014). English Literature In Indonesian High School Curriculum: Are We Ready Yet? The 61 TEFLIN International Conference, 315-320.

Rashid, R.A., Vethamani, M.E., \&, \& Rahman, S.B.A. (2010). Approaches Employed by Teachers in Teaching Literature to Less Proficient Students in Form 1 and Form 2. English Language Teaching, 3(4), 87-99. Retrieved from www.ccsenet.org/elt 
Savvidou, C. (2004). An Integrated Approach to Teaching Literature in the EFL Classroom. The Internet TESL Journal, Vol.X, No. Retrieved from http://itesl.j.oorg/

Silva Afdian dan Delvi Wahyuni. (2020). Indonesian Senior High School Students'Attitude towards Literature in English. Journal of English Language Teaching, 9(1), 160-172.

Tevdovska, E. S. (2016). Literature in ELT Setting: Students' Attitudes and Preferences Towards Literary Texts. Procedia - Social and Behavioral Sciences, 23(2), 161-169. https:// doi.org/10.1016/j.sbspro.2016.10.041
Trisnawati, R. K. (2009). Implementing ReaderResponse Theory: An Alternative Way of Teaching Literature Research Report on the Reading of Booker T Washington's Up from Slavery. Journal of English and Education, 3(1), 1-14. https://doi.org/10.20885/jee.vol3. iss1.art1

Utami, I. G. A. L. P. (2012). Learning English Through Poetry for Efl Students. Jurnal Bahasa Dan Seni, 40(1), 70-80.

Yimwilai, S. (2015). An integrated approach to teaching literature in an EFL classroom. English Language Teaching, 8(2), 14-21. https://doi.org/10.5539/elt.v8n2p14 